УДК 331.101.262

E.V. TARASEVICH, candidate of economic sciences, associate professor, Head of the department of economic and legal problems Institute of Economic and Legal Research of the NAS of Ukraine, Kyiv

\title{
HUMAN RESOURCE MANAGEMENT AS A BASIS FOR ECONOMIC DEVELOPMENT OF THE ENTERPRISE
}

Key words: human resources management, model of economic growth, investment, human capital.
The article substantiates the necessity to create quality human resources as a priority direction of development of enterprises in the context of globalization, intellectualization and dissemination of innovative technologies. The process of transformation, the role and place of man in the production and in providing strategic advantages of the company had been analyzed. Theoretical analysis of the socio-economic category of «human resources» was made in the article. The author determined factors that influence the growth of the role of human resources management in companies. The conclusion is that the theory of investment in human capital needs to be strengthened.

Introduction. In the era of globalization, intellectualization and rapid spread of innovative production technologies business priority is to develop high-quality human resources, high level of education meeting the needs of the entity, the high culture of work, a penchant for innovation. In the area of human relations is actively seeking new economic and social forms of training and formation of human resources and their effective use, reproduction and development. But the most important transformation in management, reflecting the change of the role and place of man in the production is the formation and development of the concept of human resources, which is the theoretical basis of assertions dominant role of man in productive activities and providing strategic competitive advantage. In this context, the relevance of research revealed the growing importance of the most valuable intangible asset of the company - human resources.

Analysis of recent research and publications. Various aspects of the issues devoted to the works of foreign and domestic scientists. Thus, in the works of M. Armstrong, J. Balabanov, L. Dougan, P. Drucker, Alexander Kuzmin, N. Lukyanchenko, Yu. Odegova, P. Senge, V. Travin, D. Ulrich and others covers theoretical and practical position of human resource companies are covered. But the impact of the evolution of human resources management is not developed enough in the scientific literature. The above line of research requires a deep understanding of the concept of human resources and the definition of its features as the main object and the subject of management.

In view of the purpose of the article is a theoretical analysis of the socioeconomic category of «human resources» and isolating the factors that affect the growth of the role of human resource companies. 
The results of the research. Human resources is an integral characteristic of potential employees, which reflects the totality of their intellectual and physical abilities, the production ability of people to work through the prism of the personal factor of production, which activate and create optimal conditions for its implementation is a prerequisite for productive employment.

The production function shows the extensive economic growth without taking into account the effect of intensive factors. This fact led to further modification of the Cobb-Douglas, which was carried out in two directions [1, p. 48]. The followers began to enter into the production function of exogenous (external) or endogenous (internal) index as one of the factors of scientific and technological progress. But in any model of economic growth one of the most important factors of production is labor, which embody human resources. Without human resources land and capital are dead and not suitable to meet the needs, being as necessary, but not sufficient factors of production.

The term «human resources» is closely linked with other economic concepts that define the human role in the economy, revealing the causes and conditions that ensure high efficiency of work. Related concepts consider «labor», «labor potential», «human resources», «human capital», «staff». Thus, the final definition of human resources needs to study the nature and content of these concepts. Because there is no single interpretation of terms complicates decision-making quality in the management of staff.

The basic concept that characterizes a person in the workplace activity is labor - the ability to work, which is used to produce material and spiritual goods was first used by D. Rikardo as a definition of existing capabilities of employees. The definition of Marx that has long been dominant in domestic economic thinking, labor is a combination of physical and spiritual abilities that a person has and which it uses in the production of use values [2, p. 178]. With the formation of a social market economy concept «ability to work» should be used in a broader interpretation, focusing on the person as a person who is the subject of industrial, legal, political, moral relations, not only the bearer of labor. In our view, such a relationship clearly reflects the category of «working capacity» which is in the genetic relationship to the category of «labor» by the individual as a carrier's ability to work.
The use of «working capacity» concept since 70 's XX century is a clear proof of view evaluation of the role of man in the production process, in recognition of the value of accumulated public education and intellectual potential. Analysis of publications $[3 ; 4 ; 5]$ devoted to the study of the employment potential indicates the presence of different views and approaches to the disclosure of this category. Most reasonable, in our view, is a systematic approach on which employment potential by $\mathrm{M}$. nether position is defined as «... the ability to forecast the integrated group, team, company, the working population of the country, region to productive employment of professional activity, which results in newly spiritual and material values» $[3$, p. 87].

In academic writings of some researchers $[4 ; 5]$ there is a selection of common and distinguishing features between labor potential and labor resources. In our view, the main difference between these categories is that the employment potential reflects personalized workforce who have a reserve of unrealized opportunities due to a mismatch potentially existing skills of workers with the needs of production in terms of their practical application.

Transformation of views on the human role in economic growth led to use along with the term «employment potential» concept «human capital». It is worth noting the difference between these categories. Labor potential opportunities reflect the personality and human capital determines the degree of their implementation in practice and the ability to generate income to their owner. The employment potential is the basis for the production of human capital. The founder of the theory of human capital T. Schultz realized in human capital acquired knowledge, health, skills, experience, abilities, motivation and energy that can be used over time to produce goods and services [6, p. 34]. At the same time, a number of scientists, including H. Becker, note that «Human capital - a person's ability to produce income in one form or another» [7, p. 49]. Ukrainian scientist Alexander Grishnova argues that human capital is conditionally can be interpreted as the labor potential that is realized in the marketplace in recognizing the productive nature of the investments in the economy of man [8, p. 14]. To summarize, the human capital - is accumulated generated through investments store personal qualities, the implementation of which results in the receipt of both economic 
and non-economic effects in production and nonproduction spheres of human activity. Most characteristics of the totality of employees use the concept of «footage», «personnel» «human resources». But in modern conditions of production strengthens the role of the human factor as a source of progressive growth and there is a theoretical distinction scholarly views on the nature and significance of the above terms.

Staff is a socio-economic category, which characterizes not the quality of a single individual, but a set of workers, united in the workplace to jointly achieve the goals of the company. This category reflects the main (regular) composition of qualified workers who have received special education, have the skills to perform the tasks are specialists in a particular field and are in permanent employment relationship [9, p. 500]. In some countries, only to personnel include engineering and technical staff of the enterprise: senior and middle managers, professionals with higher vocational education.

The staff is often seen as the personnel of institutions, organizations, enterprises, all permanent and temporary workers both skilled and not qualified work. This category reflects the totality of social workers who are employed with the employer, have certain quality characteristics that contribute to the strategic goals of the company. However, according to E. Korotkov, the concept of «staff» hidden deeper meaning, expressed in focusing on the role of personality in the socio-economic system [10, p. 203]. Therefore, as a function of HR personnel include both individual work (individual management) and personnel policy (management team) organization. In addition, the main difference from the category of «cadres» is the lack of permanent employment requirements and the availability of highly qualified employees. We can therefore say that the «staff» is broader and more universal term than «cadres».

In our view, the most relevant is the definition of staff as a set of specific employees of quantitative and qualitative composition united in a single manufacturing process of the ultimate purpose of the enterprise [11, p. 17]. We believe that the staff is an integral and important part of broader categories - «human resources», which at the organization reflect its personnel, which has a set of required competencies, synthesizing knowledge, skills and motivation of each employee and determine its behavior within the organization. Along with traditional characteristics that are inherent in the terms «personnel», «staff», «labor», «labor» socio-economic category «human resources», according to G. Shokin includes creativity and the full development potential employees, their culture, the effect of cooperation and self-organization, improving labor relations, etc. [12, p. 273-274].

For a long time the scientific literature the term «human resources» concerned primarily macro and micro levels of government. However, the popularization of the concept of human resource management contributed to the use of the above concepts and at the microeconomic level.

In a market economy oriented to social values, the management activities based on innovative models and aims to intellectualization of human potential. It is the human factor has a significant impact on all aspects of the production process and is the key to achievement.

Due to the modern concept of managing human resources, generally, that in policy HR advisable to focus on the following requirements:

- Defining the strategic vision of the management process for the development of human potential on a long term basis;

- The creation and effective program of systematic training to foster human development based on the disclosure of talent, intellectual abilities, competencies and motivational factors for personal needs, the objectives of the enterprise and the subsequent impact on the implementation of national priorities;

- Improving the quality of life: use the democratic style of management of human resources, in which special importance is clear and effective policy management from the perspective of professional growth, fair system of recognition and reward for contribution to improving efficiency, creating high-quality working conditions and a favorable psychological climate workplace, forming a positive organizational culture;

- Professionalization of management functions based on the need to improve organizational status, duties transformation specialists of human resource services for performance management, analytic, consulting, social functions for the effective regulation of labor partnerships to further the formation of intellectual and social capital;

- Recognition of the innovative component of human capital development and implementation of advanced technologies, personnel management and human resource development; 
- Investment in human capital to obtain economic benefits from investment and sustainable development.

By investing finance, time and intellectual resources for workers, companies increase the efficiency of work by enhancing employment of staff, stimulation and increase their motivation; reduce the cost of work that the resulting positive impact on achieving objectives and strengthen competitiveness. At the same time financial resources invested in the process of training and skills to achieve business objectives; for prevention, corporate and social events in general, to improve standards and quality of life [13, p. 123-124].

Thus, the analysis related categories makes it possible to argue that they are complementary concepts, and their occurrence and distribution of human values caused by the transformation of the components in the evolutionary development. These categories inherent evolutionary nature, which correlates with the dynamics of the transition from technocratic to consider human values position as a major source of progressive growth.

Based on an analysis of reasonable definition of human resources and adjacent categories, believe in human resources at the microeconomic level should understand the socio-economic concept that reflects the existing and hidden features people and dialectical totality corporate, professional, social and personal competencies of employees, identification and improvement which is the basis for the functioning and development of the company.

Currently, there is formation of human management concept, according to which a person is the main subject of the company and a particular object management, and strategy and structure of the company are based on the evaluation and development of human competence. In our view, this concept is an organic complement of the concept of human resource management, which is the most common practice that necessitates analyzes of the latter.

At the present stage transition from the «economic rights» to «social rights» requires consideration of personal factors impact on personnel management of any entity. Innovative staff motives and incentives to work, wish fulfillment in the workplace increases the demands on companies for their support, and increase educational and cultural level of the workers reflected on the price of labor, employment and employees.
Thus, taking into account personal factors in the management of human resources, activation of logical and emotional intelligence officer is a prerequisite for enterprise development, gaining them new competitive advantages accordance with the socio-economic changes.

Importance of human resources for the company emphasizes theory of investment in human capital (T. Schultz, H. Becker, B. Veysbrod, J. Mintser, L. Hansen), the core of which is the relationship between investments in human capital and economic development. Based on this theory, man is not a factor of production, and a specific element that is in constant development and is considered the most valuable asset.

It is recognized that investment in training and development of employees enhance their skills and professionalism, turning them into component production and business systems, highly qualified staff is a generator of new ideas and a catalyst for innovation in practice, initiated expanding the range of expertise. The concept of human resource management is based on prioritization, feasibility of investments that are invested in employees, their training and development, creating conditions for self-realization and self-affirmation.

It should be noted about the new trends in human resource management, the most important of which are: the professionalization of human resources; transition from fragmented training employees to integrative holistic personality development; temporary shift of individual training on the formation of a learning organization; the use of flexible, adaptive systems for human resource development and its focus on the final results of the company; distribution system of employee participation in profits and different systems of collective bonuses (Skenlona, Rakkera, Improshear) to increase the efficiency incentives for workers; change the functions of specialist HR: from conventional personnel officer, a professional coach who owns a set of modern personnel technologies and methods of human development.

Conclusion. Summarizing the genesis of the concept of human resource management consider it appropriate to formulate proper understanding of the concept. In our view, human resource management system of mutually coordinated measures to create, efficiency and quality growth opportunities and competence of employees in order to optimize business processes. This necessitates finding and implementing modernized approaches

ISSN 1681-6277. Економіка та право. № 2 (44), 2016 
to human resource management, based on the basic principles of staff management, along with new effective tools (techniques, methods, evaluation criteria) management, given the competitive potential ofhuman resources.

\section{REFERENCES}

1. Grabovetsky B. E. (2009), Productionfunctions: Theory, construction, use in production management: monograph, Universum, Vinnitsa, Ukraine.

2. Marx K. and Engels F. (2009), Works, 2nd ed, T. 23, Progress, Kyiv, Ukraine.

3. Dolishniy M.I. (2009), Social and psychological components of labor potential, Demographic aspects of labor potential reproduction, vol. 3, pp. 87-91.

4. Pityulych M.I., Biben M.I. and Miklovda V.V. (2009), Employment potential of the region, development strategy and operation, Karpaty, Uzhgorod, Ukraine.

5. Khlopova T. (2009), Development of employment and competitiveness bulding workers in modern conditions, BGUEP Publishing House, Irkutsk, Russia.

6. Schultz T.W. (1971), Investment in Human Capital, The American EconomicRevier, vol. 51, pp. 1-17.

7. Becker G.S. (1994), Investment in Human capital: A Theoretical and Empirical Analysis, Journal of Political Economy, vol. 70, pp.9-49.

8. Hoishnova O.A. (2009), Humancapital: formation in education and training, Knowledge, Kyiv, Ukraine.

9. Odegova G. (2009), Economystaff. Theory: textbook, P.I, AlphaPress, Moscow, Russia.

10. Korotkov E. M. (2010), Concept of Management: textbook, IKK Deca, Moscow, Russia.

11. Kryzhko I.D., Bogdanova T.I., Vedernikov M.D., (1999), Formation of professional human resources officer structure: monograph, SPE Eureka, Khmelnitsky, Ukraine.

12. Schekyn G.V. (1999), Theory and practice of management personnel: ucheb. method, posob, 2nd ed, MAUs, Kyiv, Ukraine.

13. Revina O.M. (2015), Organizational-economic bases of management of human potential of rail transport in terms of intellectualization ekonomy, Abstract of Sc. Ec. dissertation, Economics and Enterprise Management, State Economy and Technology University of Transport, Kyiv, Ukraine.

Надійшла 09.06.2016

\section{О.В. Тарасевич}

Інститут економіко-правових досліджень

НАН України, м. Київ

\section{УПРАВЛІННЯ ЛЮДСЬКИМИ РЕСУРСАМИ ЯК ОСНОВА ЕКОНОМІЧНОГО РОЗВИТКУ ПІДПРИЕМСТВА}

У статті обгрунтовано необхідність формування якісних людських ресурсів як пріоритетного напряму розвитку підприємств в умовах глобалізації, інтелектуалізації та поширення інноваційних технологій. Проаналізовано процеси трансформації, ролі й місця людини на виробництві та у забезпеченні стратегічних переваг підприємства. Виконано теоретичний аналіз соціально-економічної категорії «людські ресурси». Виокремлено фактори, які впливають на зростання ролі управління людськими ресурсами підприємств. Зроблено висновок щодо необхідності посилення теорії інвестування в людський капітал.

Ключові слова: людські ресурси, управління, модель економічного зростання, інвестування, людський капітал.

\section{Е.В. Тарасевич}

Институт экономико-правовых исследований НАН Украины, Киев

\section{УПРАВЛЕНИЕ ЧЕЛОВЕЧЕСКИМИ РЕСУРСАМИ КАК ОСНОВА ЭКОНОМИЧЕСКОГО РАЗВИТИЯ ПРЕДПРИЯТИЯ}

В статье обоснована необходимость формирования качественных человеческих ресурсов как приоритетного направления развития предприятий в условиях глобализации, интеллектуализации и распространения инновационных технологий. Проанализированы процессы трансформации, роли и места человека на производстве и в обеспечении стратегических преимуществ предприятия. Проведен теоретический анализ социально-экономической категории «человеческие ресурсы». Выделены факторы, влияющие на рост роли управления человеческими ресурсами предприятий. Сделан вывод о необходимости усиления теории инвестирования в человеческий капитал.

Ключевые слова: человеческие ресурсы, управление, модель экономического роста, инвестирование, человеческий капитал. 